\title{
PENGARUH GARAM NaCI TERHADAP KINERJA PROSES BIOLOGIS ANAEROBIK
}

\author{
Oleh : I k b a I \\ Kelompok Teknologi Pengelolaan Air Bersih Dan Limbah Cair, Pusat Pengkajian Dan
PenerapanTeknologi Lingkungan, BPPT
}

ABSTRAK

\begin{abstract}
Anaerobic treatment of synthetic wastewater with a high $\mathrm{NaCl}$ content was investigated for its effect on the process. The synthetic wastewater, including $\mathrm{NaCl}$ up to $40 \mathrm{~g} / \mathrm{l}$, was treated anaerobically by draw-and-fill method at a treatment temperature of $37^{\circ} \mathrm{C}$ and volumetric loading of rate TOC of $1 \mathrm{~g} / \mathrm{l} / \mathrm{d}$. TOC removal efficiency and rate of gas evolution rate gradually decreased as salt content increased, although stable operation was maintained. TOC removal efficiency remained high at concentration of $\mathrm{NaCl}$ up to $20 \mathrm{~g} / \mathrm{l}$, although it fell to $82 \%$ at $30 \mathrm{~g} \mathrm{NaCl} / \mathrm{l}$. The gas yield at 10, 20 and $30 \mathrm{~g} \mathrm{NaCl/l}$ were 1.35; 1.10 and $1.00 \mathrm{l} / \mathrm{g}$-TOC loaded, which corresponded to 96; 83 and $78 \%$ of that without $\mathrm{NaCl}$, respectively. The content of methane in the evolved gas was 50 to $55 \%$ throughout the experiment. Stable operation could not be maintained at $40 \mathrm{~g}$ $\mathrm{NaCl/l}$ since the TOC removal efficiency gradually decreased with the rapid increased in levels of volatile fatty acids
\end{abstract}

Kata kunci : fermentasi metana, garam $\mathrm{NaCl}$, konduktifitas, asam-asam organik, biogas

\section{PENDAHULUAN}

Proses biologis anaerobik atau fermentasi metana adalah cara pengolahan limbah yang sudah cukup lama dikenal dan ekonomis. Pada awal tahun 1900, proses ini sudah diaplikasikan di Inggris untuk mengolah lumpur organik yang berasal dari kolam pengendap pada unit pengolahan limbah cair domestik ${ }^{1}$. Selanjutnya proses ini dikembangkan untuk mengolah limbah cair industri, khususnya yang mempunyai polutan organik tinggi. Dibandingkan dengan biologi aerobik, proses anaerobik mempunyai beberapa keunggulan, diantaranya;

1. Hemat energi. Pada pengolahan anaerobik, proses penguraian polutanpolutan organik oleh mikroba berlangsung pada kondisi tanpa udara, sehingga tidak diperlukan energi untuk mensuplai udara.

2. Menghasilkan biogas (gas metana). Salah satu produk akhir hasil penguraian polutan organik adalah gas metana $\left(\mathrm{CH}_{4}\right)$ yang dapat dimanfaatkan sebagai bahan bakar gas.

3. Mampu mengolah limbah organik berkonsentari tinggi, yaitu sampai $\mathrm{BOD}_{5}$ $80.000 \mathrm{mg} / \mathrm{l}^{2}$.

4. Lumpur organik (surplus sludge) yang dihasilkan lebih sedikit dan dengan mudah dapat dimanfaatkan sebagai bahan baku pupuk organik (kompos).

Selanjutnya, untuk memperluas bidang operasional pengolahan biologi anaerobik, proses ini kemudian dikembangkan lagi untuk mengolah limbah-limbah organik yang mepunyai karakteristik khusus. Misalnya, Kamagata $\mathrm{dkk}^{3}{ }^{3}$ melakukan

penelitian pengolahan limbah senyawa benzoat. Fukuzaki dkk. 4) meneliti pengaruh senyawa propionat dan Wang dkk. ${ }^{5}$ meneliti pengaruh senyawa phenol terhadap kinerja proses fermentasi metana. Penelitian pengolahan limbah industri pulp yang mengandung senyawa methanol dilakukan oleh Minami dkk. ${ }^{6)}$. Kemudian Ikbal dkk. ${ }^{7)}$ meneliti pengaruh $\mathrm{pH}$, nitrat $\left(\mathrm{NO}_{3}{ }^{-}\right)$, sulfida $\left(\mathrm{S}^{2-}\right)$, propionat dan asetat terhadap aktivitas mikroba pembentuk gas metana (methanogenic activity). Mereka juga melaporkan bahwa konsentrasi $\mathrm{NH}_{4}{ }^{+}$dalam bioreactor sebesar $2.000 \mathrm{mg} / \mathrm{l}$ pada $\mathrm{pH} 8$ akan mengurangi produksi biogas sebanyak $40 \%$. Kemudian untuk meningkatkan kinerja proses anaerobik, Ikbal dkk. 7) meneliti pengaruh penambahan logam $\mathrm{Co}^{2+}$ dan $\mathrm{Ni}^{2+}$, dan menyimpulkan bahwa penambahan masingmasing logam diatas sampai konsentrasi $10 \mathrm{mg} / \mathrm{l}$ kedalam air limbah akan meningkatkan aktivitas mikroba pembentuk gas metana yang ditandai dengan bertambahnya produksi biogas.

Meskipun penelitian untuk meningkatkan kinerja proses biologi anaerobik telah banyak dilakukan, tetapi informasi tentang pengaruh garam $\mathrm{NaCl}$ terhadap proses belum begitu memadai, pada hal seperti diketahui garam $\mathrm{NaCl}$ cukup banyak terdapat didalam air limbah.

Penelitian ini bertujuan untuk melihat pengaruh konsentrasi $\mathrm{NaCl}$ terhadap kinerja 
proses anaerobik, serta untuk mengetahui konsentrasi $\mathrm{NaCl}$ maksimum didalam air limbah yang masih bisa ditolerir.

\section{BAHAN DAN METODA}

\subsection{Air Limbah}

Komposisi air limbah sintetis yang digunakan adalah sebagai berikut ( $\mathrm{g} / \mathrm{l})$. Glukosa, 35; corn steep liquor, 35; $\mathrm{KH}_{2} \mathrm{PO}_{4}, \quad 2$; $\left(\mathrm{NH}_{4}\right)_{2} \mathrm{CO}_{3} . \mathrm{H}_{2} \mathrm{O}, 5 ; \mathrm{Na}_{2} \mathrm{CO}_{3}, 3$; dan $\mathrm{FeCl}_{3} .6 \mathrm{H}_{2} \mathrm{O}$, 1. Glukosa dan corn steep liqour (hasil samping pada industri pengolahan jagung) digunakan sebagai sumber senyawa karbon. Untuk melihat pengaruh garam $\mathrm{NaCl}$ terhadap kinerja proses, kedalam limbah sintetis ditambahkan $\mathrm{NaCl}$ padat sampai diperoleh beberapa buah konsentrasi yang diinginkan. Kandungan organik (organic matter) dan konsentrasi TOC (total organik karbon) limbah sintesis masing-masing adalah 50.000 dan $18.800 \mathrm{mg} / \mathrm{l}$.

\section{2 Mikroba}

Mikroba anaerobik yang digunakan pada penelitian ini diperoleh dari unit pengolahan lumpur organik limbah domestik. Sebelum digunakan, mikroba diaktifkan atau diaklimatisasi selama beberapa bulan di laboratorium.

\subsection{Peralatan penelitian}

Gambar 1 adalah rangkaian peralatan yang digunakan untuk penelitian. Sebagai bioreaktor dipakai empat buah botol gelas bermulut lebar (reaktor 1, 2, 3 dan 4), dengan volume kerja masing-masing $400 \mathrm{ml}$. Botol dilengkapi dengan penutup karet yang diberi dua buah lobang. Satu lobang untuk aliran biogas ke tempat penampung (gas holder) dan satu lagi untuk tempat sampling. Mula-mula kedalam masing-masing botol dimasukkan kultur mikroba sebanyak $400 \mathrm{ml}$, kemudian botol ditutup rapat. Biogas yang terbentuk selama proses berlangsung mengalir ke tempat penampung gas. Botol-botol dimasukkan kedalam wadah air pemanas (water bath) yang dilengkapi dengan alat pengontrol suhu. Selama penelitian suhu dipertahankan pada $37^{\circ} \mathrm{C}$, kecepatan pengadukan 300 rpm. Mula-mula kultur mikroba dalam bioreaktor diaklimatisasi dengan limbah sintetis tanpa $\mathrm{NaCl}$ selama 2 minggu pada beban organik $1 \mathrm{~g} / \mathrm{l} / \mathrm{d}$ dengan cara draw-and-fill, yaitu cairan didalam bioreaktor diambil sejumlah tertentu, kemudian limbah segar dalam jumlah yang sama dimasukkan kedalam bioreaktor. .Aklimatisasi adalah proses pengadaptasian atau penyesuaian mikroba dengan kondisi lingkungan dan makanannya. Setelah 2 minggu, kemudian proses aklimatisasi dilanjutkan dengan limbah sintetis yang mengandung garam $\mathrm{NaCl}$ pada 4 macam konsentrasi $(40,60,85$ dan $140 \mathrm{~g} / \mathrm{l})$ sampai nilai konduktifitas cairan didalam bioreaktor sama dengan nilai konduktifitas garam $\mathrm{NaCl}$ pada konsentrasi yang akan diteliti $(10,20$, 30 dan $40 \mathrm{~g} / \mathrm{l}$ ).

\section{$2.4 \quad$ Analisa}

Semua parameter, kecuali $\mathrm{pH}$ dan konduktifitas, yang dianalisa adalah supernatannya. Supernatan dipisahkan dari padatan dengan alat sentrifugator (MLX-150, TOMY, Tokyo) yang dioperasikan pada kecepatan $10.000 \mathrm{rpm}$ selama 10 menit. TOC (total organic carbon) diukur menggunakan TOC autoanalyzer (TOC-500; Shimadzu, Kyoto). Asam-asam organik bermolekul rendah (volatile fatty acids/VFA) dianalisa dengan metoda postlabel method. Asam-asam organik dalam limbah direaksikan dengan larutan bromothymol blue, kemudian diukur pada gelombang $450 \mathrm{~nm}$ dengan alat detektor (detector model 870-UV; Japan Spectroscopic Co. Ltd., Kyoto) setelah asam-asam organik dalam limbah difraksinasi dengan HLPC (high-performance liquid chromatography/ 880-PU, 860-CO; Japan Spectroscopic Co. Ltd.) menggunakan kolom (Shim-pack SCR-101H; Shimadzu, Kyoto). pH cairan diukur dengan $\mathrm{pH}$ meter (HM-25G, DKKTOA, Co., Tokyo). Konduktifitas diukur dengan alat conductivity meter (AOL-40; Denki Kagaku Keiki Co. Ltd., Tokyo). Konsentrasi gas $\mathrm{CH}_{4}$ dan $\mathrm{CO}_{2}$ dalam biogas diukur menggunakan TCD gas chromatography (KOR-2G; Gasukuro Kogyo Inc., Tokyo) memakai kolom (Porapak Q; Gasukuro Kogyo Inc., Tokyo).

\section{HASIL DAN DISKUSI}

\subsection{Hubungan konsentrasi NaCl dengan}

Pertama-tama dibuat grafik hubungan antara konsentrasi $\mathrm{NaCl}$ dalam air limbah dengan nilai konduktifitasnya. Caranya yaitu dengan menambahkan garam $\mathrm{NaCl}$ dalam jumlah tertentu kedalam air limbah sampai diperoleh konsentrasi yang diinginkan, kemudian pada masing-masing konsentrasi tersebut diukur konduktifitasnya. Gambar 2 adalah grafik hubungan antara konsentrasi $\mathrm{NaCl}$ yang dibuat dengan konduktifitas hasil pengukuran yang dilakukan.

Selanjutnya, selama penelitian berlangsung, konsentrasi $\mathrm{NaCl}$ didalam effluen bioreaktor didapat dengan cara mengukur konduktifitas cairan tersebut, kemudian nilai konduktifitas yang diperoleh diplotkan pada grafik gambar 2, maka akan diketahui konsentrasi $\mathrm{NaCl}$ dalam 
cairan effluen tersebut. Dari studi leteratur diketahui bahwa konsentrasi garam $\mathrm{NaCl}$ dalam air limbah sebesar $20 \mathrm{~g} / \mathrm{l}$, menyebabkan produksi biogas turun secara drastis. Berdasarkan literatur tersebut, maka pada penelitian ini akan dilihat pengaruh garam $\mathrm{NaCl}$ pada konsentrasi $10,20,30$ dan $40 \mathrm{~g} / \mathrm{l}$ terhadap kestabilan proses.

\subsection{Proses aklimatisasi}

Setelah mikroba diaklimatisasi dengan limbah tanpa $\mathrm{NaCl}$ selama 2 minggu, proses aklimatisasi dilanjutkan dengan limbah sintetis yang mengandung $\mathrm{NaCl}$. Selama masa aklimatisasi, konsentrasi $\mathrm{NaCl}$ didalam bioreaktor akan naik secara bertahap. Agar konduktifitas cairan dalam bioreaktor setelah 10 hari masa aklimatisasi sama dengan konduktifitas air limbah yang akan diuji yaitu konduktifitas $\mathrm{NaCl}$ pada konsentrasi $\mathrm{NaCl} 10,20$, 30 dan $40 \mathrm{~g} / \mathrm{l}$, maka jumlah $\mathrm{NaCl}$ yang harus ditambahkan kedalam air limbah umpan bioreaktor harus dihitung dengan persamaan berikut ${ }^{8)}$ :

$C_{n}=\left\{\left(V-V_{f} / V\right\}^{n}\left(C_{o}-C_{i}\right)+C_{i}\right.$

dimana:

$\mathrm{V}=$ volume kerja bioreaktor $(\mathrm{ml})$

$\mathrm{V}_{\mathrm{f}}=$ volume draw-and-fill $(\mathrm{ml})$

$\mathrm{C}_{\mathrm{n}}=$ konduktifitas cairan dalam bioreaktor setelah hari ke $n(\mathrm{mS} / \mathrm{cm})$

$\mathrm{C}_{0}=$ konduktifitas awal cairan dalam bioreaktor ( $\mathrm{mS} / \mathrm{cm})$

$\mathrm{C}_{\mathrm{i}}=$ konduktifitas air limbah umpan bioreaktor (mS/cm)

Dalam persamaan (1), kenaikan konduktifitas cairan dalam bioreakor yang disebabkan oleh kenaikan konsentrasi asamasam organik dapat diabaikan, karena dari hasil percobaan diketahui bahwa kenaikan ini sangat kecil, hanya $4 \mathrm{mS} / \mathrm{cm}$ pada konsentrasi asamasam organik $8.000 \mathrm{mg} / \mathrm{l}$.

Dengan menggunakan persamaan (1), dimana volume bioreaktor (V), $400 \mathrm{ml}$; volume draw-and-fill $\left(V_{f}\right), 20 \mathrm{ml}$ (setara dengan beban organik $1 \mathrm{~g} / \mathrm{l} / \mathrm{d}$ ); konduktifitas awal cairan dalam bioreaktor $\left(\mathrm{C}_{0}\right), 18 \mathrm{mS} / \mathrm{cm}$; konduktifitas cairan dalam masing-masing bioreaktor setelah hari ke $10\left(C_{10}\right)$ yaitu sama dengan konduktifitas larutan $\mathrm{NaCl}$ pada konsentrasi 10; 20; 30 dan $40 \mathrm{~g} / \mathrm{l}$, masing-masing 25; 40; 50 dan $60 \mathrm{mS} / \mathrm{cm}$; maka akan didapatkan konduktifitas cairan umpan bioreaktor $(\mathrm{Ci})$ yaitu masing-masing sebesar 60 ; 75; 90 dan $120 \mathrm{mS} / \mathrm{cm}$. Kemudian dengan menggunakan grafik pada gambar 2, maka akan diketahui jumlah garam $\mathrm{NaCl}$ yang harus ditambahkan kedalam limbah sintetis umpan bioreaktor, yaitu masing-masing 40; 60; 85 dan
$140 \mathrm{~g} / \mathrm{l}$ untuk reaktor 1, 2, 3 dan reaktor 4 . Setelah 10 hari proses aklimatisasi dengan limbah sintetis mengandung $\mathrm{NaCl}$, nilai konduktifitas cairan dalam bioreaktor mencapai nilai yang diinginkan yaitu 25; 40; 50 dan 60 $\mathrm{mS} / \mathrm{cm}$. Selanjutnya umpan bioreaktor diganti dengan limbah $\mathrm{NaCl}$ berkonsentrasi 10; 20; 30 dan $40 \mathrm{~g} / \mathrm{l}$. Gambar 3 adalah hasil pengamatan harian pada 4 buah bioreactor tersebut. Selama masa aklimatisasi, konduktifitas dalam bioreaktor naik secara bertahap dan sampai pada nilai yang diinginkan setelah 10 hari proses aklimatisasi.

\subsection{Pengaruh konsentrasi $\mathrm{NaCl}$}

Seperti terlihat pada gambar 3 , setelah proses aklimatisasi selesai, konduktifitas cairan dalam bioreaktor tetap stabil pada konduktifitas masing-masing konsentrasi $\mathrm{NaCl}$ yang diteliti.

Effisiensi pengurangan TOC pada umpan dengan konsentrasi $\mathrm{NaCl} 10 \mathrm{~g} / \mathrm{l}$ (reator 1) sedikit naik sampai $93 \%$ pada hari ke 25 . Kenaikan ini disebabkan karena penurunan konsentrasi asam-asam organik dalam bioreaktor, dimana seperti diketahui sebagian dari TOC adalah asam-asam organik. Asam-asam organik seperti asam laktat, asam asetat, asam propionat, asam butirat dam asam valeriat merupakan produk antara pada penguraian material organik komplek menjadi biogas pada proses biologi anaerobik. Akomulasi asam-asam tersebut didalam bioreaktor akan menyebabkan kestabilan proses terganggu, bahkan lebih jauh dapat mengakibatkan kegagalan proses. Effisiensi pengurangan TOC dan konsentrasi asam-asam organik hampir tidak berubah pada konsentrasi $\mathrm{NaCl} 20 \mathrm{~g} / \mathrm{l}$ (reaktor 2) yaitu masingmasing sekitar 90\%, 3.000-3.500 mg/l dan hampir $85 \%$ didalam asam organik adalah asam asetat yang relatif mudah diuraikan menjadi biogas. Pada konsensentrasi $\mathrm{NaCl} 30 \mathrm{~g} / \mathrm{l}$ (reaktor 3), asam-asam organik naik secara gradual, kemudian stabil pada konsentrasi $5.700 \mathrm{mg} / \mathrm{l}$. Sejalan dengan akomulasi asam-asam organik ini effisiensi pengurangan TOC juga menurun, namun kemudian stabil pada level sekitar $82 \%$ setelah hari ke 15 . Tetapi hasil yang sangat kontras terlihat pada konsentrasi $\mathrm{NaCl} 40 \mathrm{~g} / \mathrm{l}$ (reaktor 4), dimana effisiensi pengurangan TOC turun secara drastis yang menyebabkan kestabilan proses tidak dapat dipertahankan. Seperti terlihat pada gambar 3, kondisi ini disebabkan karena terjadi akomulasi asam-asam organik didalam bioreaktor, dimana konsentrasinya naik sampai 10.000 mg/l pada hari ke 15. Komponen utama asam organik disini adalah asam propionat $6.100 \mathrm{mg} / \mathrm{l}$. Seperti diketahui, asam propionat sangat sukar diuraikan pada proses biologi anaerobik karena reaksi penguraiannya bersifat endotermis atau 
memerlukan panas ${ }^{9}$ ). Akomulasi asam propionat sering sekali menyebabkan gagalnya proses fermentasi metana. $\quad \mathrm{pH}$ didalam bioreaktor dapat dipertahankan stabil diatas 7 pada konsentrasi $\mathrm{NaCl}$ sampai $30 \mathrm{~g} / \mathrm{l}$. Tetapi turun sampai dibawah 6 pada konsentrasi $\mathrm{NaCl}$ $40 \mathrm{~g} / \mathrm{l}$, disebabkan karena tingginya konsentrasi asam-asam organik dalam bioreaktor.

Sebagai perbandingan, Renzima dkk. ${ }^{10)}$ melaporkan bahwa $\mathrm{NaCl}$ pada konsentrasi $14 \mathrm{~g} / \mathrm{l}$ pada umpan bioreaktor mengakibatkan produksi biogas berhenti sama sekali karena akomulasi asam-asam organik. Sonoda dkk. 11) juga melakukan penelitian yang sama menggunakan bioreaktor bervolume $50 \mathrm{ml}$ dan melaporkan bahwa penambahan $\mathrm{NaCl}$ pada konsentrasi 20 $\mathrm{g} / \mathrm{l}$, produksi biogas berkurang sampai $80 \%$. Penelitian-penelitian diatas mereka lakukan tanpa terlebih dulu melakukan proses aklimatisasi mikroba. Pada penelitian kali ini, konsentrasi $\mathrm{NaCl}$ maksimum yang dapat diolah mencapai 2 kali lebih besar bila dibanding dengan peneliti sebelumnya. Hal ini barangkali disebabkan karena sebelum penelitian dimulai, terlebih dulu dilakukan proses aklimatisasi mikroba.

Gambar 4 menyajikan rangkuman hasil penelitian, memuat konsentrasi asam-asam organik, effisiensi pengurangan TOC, konsentrasi gas metana dan produksi biogas pada kondisi stabil tiap-tiap konsentrasi $\mathrm{NaCl}$ yang diteliti. Effisiensi pengurangan TOC dan produksi biogas berkurang sejalan dengan kenaikan konsentrasi $\mathrm{NaCl}$ dalam limbah sintetis. Produksi biogas pada konsentrasi $\mathrm{NaCl} 10 ; 20$ dan $30 \mathrm{~g} / \mathrm{l}$ masing-masing adalah 1,35; 1,10 dan 0,96 l/g-TOC umpan, atau 96; 83 dan $78 \%$ dari produksi biogas pada limbah sintetis tanpa penambahan $\mathrm{NaCl}$ (blank). Akomulasi asamasam organik naik secara signifikan pada kenaikan konsentrasi $\mathrm{NaCl}$. Kandungan gas metana dalam biogas hampir tidak berubah, selama penelitian berlansung berkisar antara 45$50 \%$.

\section{KESIMPULAN}

Dari pembahasan dan diskusi diatas dapat disimpulkan bahwa kenaikan konsentrasi $\mathrm{NaCl}$ dalam air limbah sampai $20 \mathrm{~g} / \mathrm{l}$ tidak mempengaruhi aktifitas mikroba, dan pada konsentrasi $\mathrm{NaCl} 30 \mathrm{~g} /$ terjadi sedikit penurunan effisiensi pengolahan. Akumulasi asam-asam organik di dalam bioreaktor pada konsentrasi $10.000 \mathrm{mg} / \mathrm{l}$ akan menyebabkan kegagalan proses pengolahan. Proses aklimatisasi mikroba sangat diperlukan karena dapat meningkatkan daya tahan dan aktifitas mikroba.

\section{DAFTAR PUSTAKA}

1. Mc Carty, P.L. : One hundred years of anaerobic traetment, Elsevier Biomedical Press B.V., Amsterdam (1982).

2. Kida. K, Ikbal, Sonoda, Y., Kawase, M., and Nomura, T.: Influent of mineral nutrients on high performance during anaerobic treatment of wastewater from beer brewery. J. Ferment. Bioeng. 72, 54-57(1991).

3. Kamagata, Y., Kitagawa, N., Tasaki, M., Nakamura, K., and Mikami, E.: Degradation of benzoate by an anaerobic consortium and same properties of a hydrogenotrophic methanogen and sulfate-reducing bacterium in the consortium. J. Ferment. Bioeng., 73, 213-218 (1992).

4. Fukuzaki, S., Nishio, N., Sakurai, H., and Nagai, S.: Characteristics of methanogenic granules grown on propionate in an UASB reactor. J. Ferment. Bioeng., 71, 50-57 (1991).

5. Wang, Y. T., Suida, M. T., and Rittman, B. E.: Anaerobic treatment of phenol by an expended-bed reactor. J. WPCF, 58, 227233 (1986).

6. Minami, K., Horiyama, T., Tasaki, M., and Tanimoto, Y.: Methane production using a bio-reactor packed with pumice stone on an evaporator condensate of a kraft pulp mill. J. Ferment. Technol., 64, 523-532 (1986).

7. Ikbal, Tang, Y., Fujimura, Y., Shigematsu, T., Morimura, S., and Kida, K.: The affecting factors for optimization of mesophilic aceticlastic methanogenesis. Japan J. Water Treat. Biol. 39, 189-197 (2003).

8. Tanemura, K., Kida, K., Ikbal, Matsumoto, J., and Sonoda, Y.: Anaerobic treatment of wastewater with high salt content from a picklet-plum manufacturing process. J. Ferment. Bioeng. 77, 188-193 (1994).

9. Kida, K., Morimura, S., and Sonoda, Y.: Accumulation of propionic acid during anaerobic treatment of distillery wastewater from barely-shochu making. J. Ferment. Bioeng., 75, 213-216 (1993).

10. Renzima, A., van Lier, J., and Lettinga, G.: Sodium inhibition of acetoclastic methanogens in granular sludge from a UASB reactor. Enzym Microb. Technol., 10, 24-32 (1988).

11. Sonoda, Y., and Seiko, Y.: Degradation and toxity of various compounds in anaerobic digestion. Hakkokogaku, 55, $22-29$ (1977). 


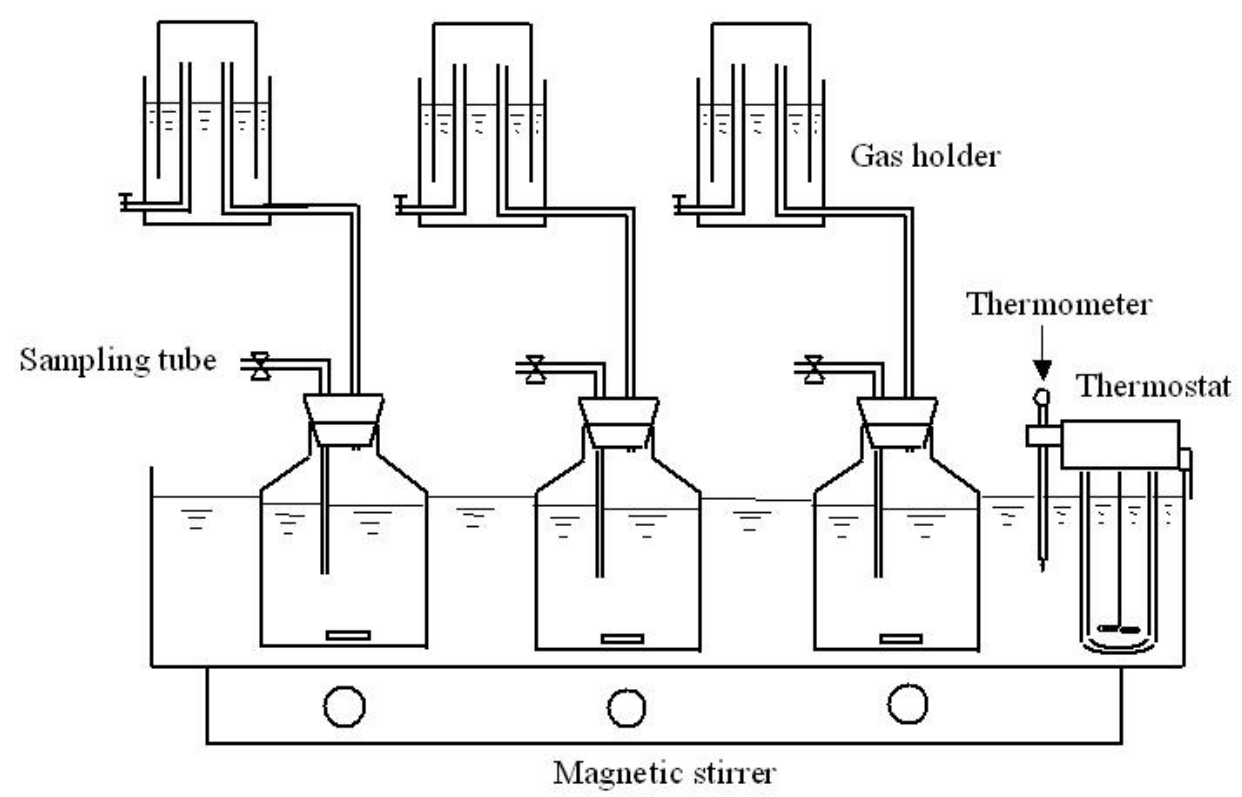

Gambar 1. Rangkaian peralatan penelitian proses pengolahan biologi anaerobik

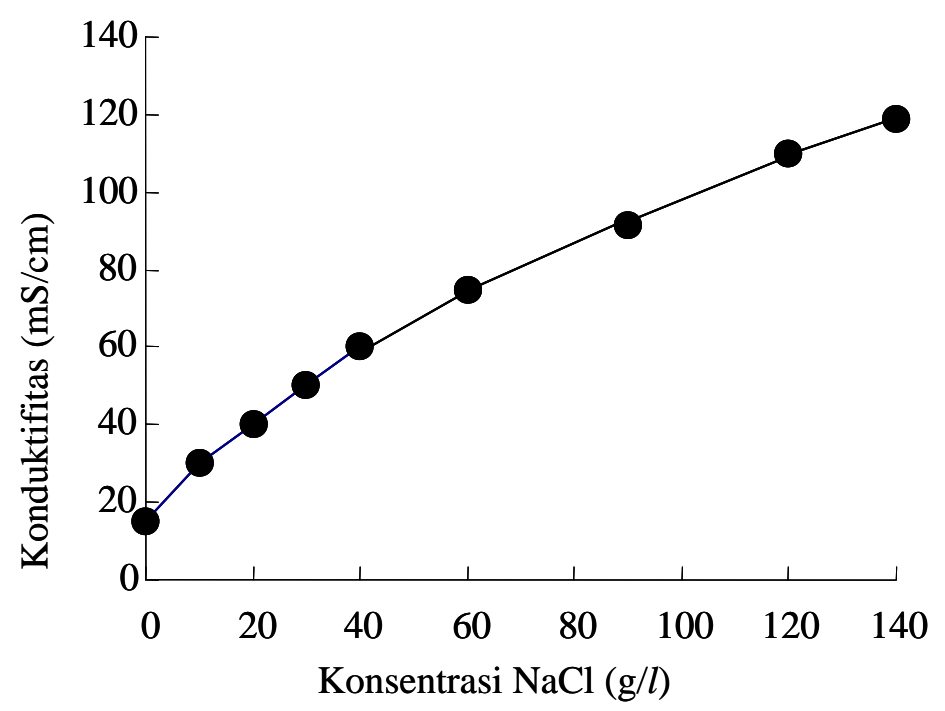

Gambar 2. Hubungan antara konsentrasi $\mathrm{NaCl}$ dengan konduktifitas 


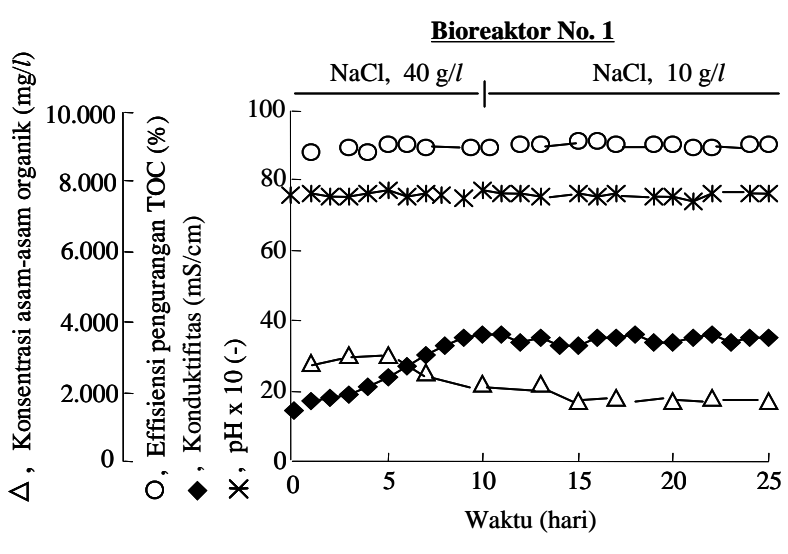

Bioreaktor No. 2

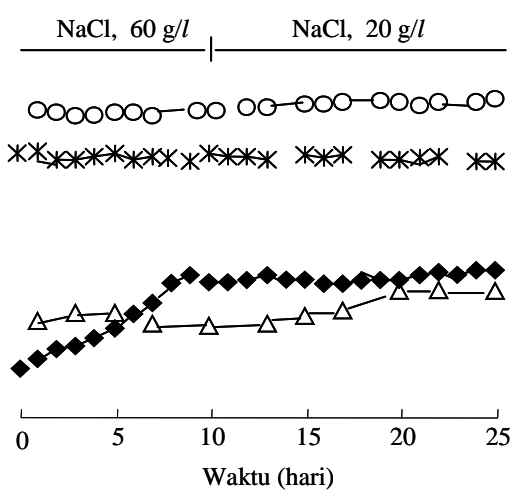

Bioreaktor No. 3

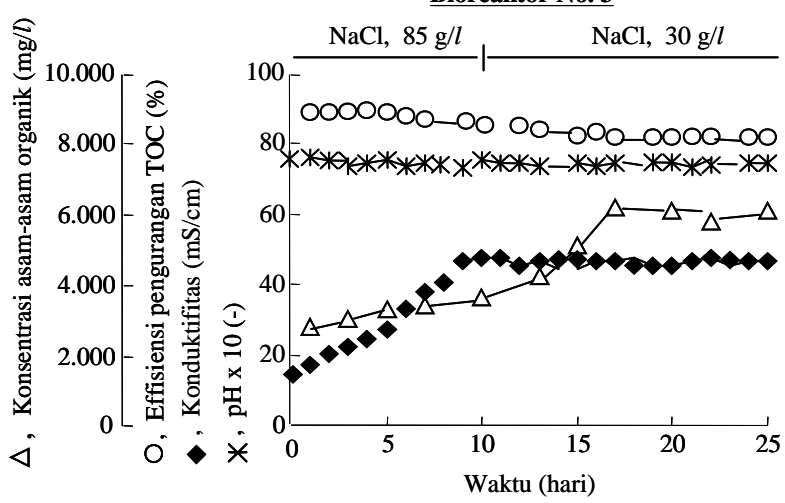

Bioreaktor No. 4

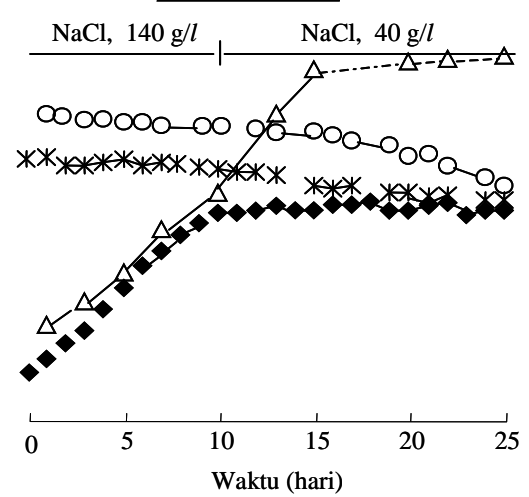

Gambar 3. Perubahan konduktifitas, $\mathrm{pH}$, effisiensi pengurangan TOC dan konsentrasi asam-asam organik selama proses pengolahan biologi anaerobik

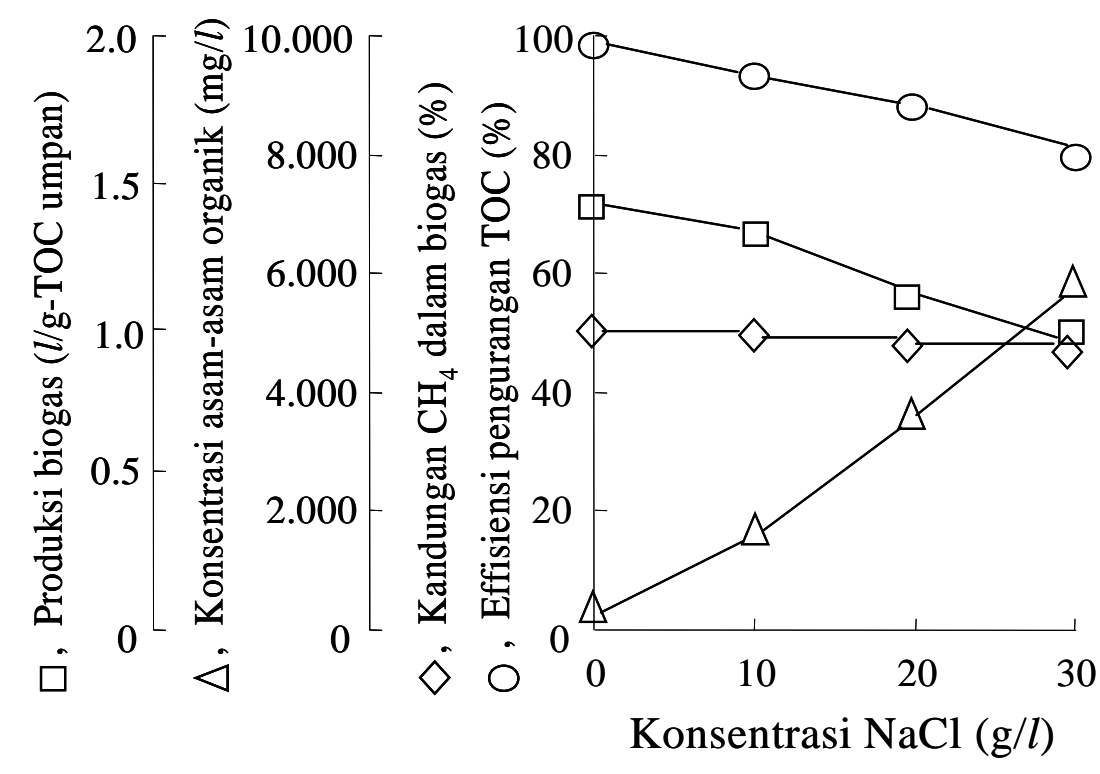

Gambar 4. Pengaruh konsentrasi NaCl terhadap effisiensi proses pengolahan biologi anaerobik 